\title{
Da literatura indianista à
}

\section{literatura indígena: sobre a}

\section{imagem, o lugar e o protagonismo}

\section{indígena em termos de}

\section{constituição da identidade cultural brasileira!}

LENo Francisco Danner

Professor no departamento de filosofia da Universidade Federal de Rondônia

JULIE DORRICO

Doutoranda em Teoria Literária na PUC-Rio Grande do Sul

FERNANDO DANNER

Professor no departamento de filosofia da Universidade Federal de Rondônia

O índio que se conhece até hoje, nestes últimos soo anos,

é o índio teatralizado. Infelizmente, para a maior parte da população brasileira, o índio é um personagem, não existe de fato. (...)

O que aconteceu aqui no Brasil, há 500 anos, CNPq.

${ }^{I}$ Pesquisa financiada pelas seguintes agências de fomento à pesquisa: FAPERO, CAPES e 
foi uma teatralização dos povos ancestrais,

foi assim que nasceu o Brasil $\left.\right|^{2}$

\section{Considerações Iniciais}

$\mathrm{O}$ artigo objetiva refletir sobre a constituição da identidade cultural brasileira a partir de um diálogo entre a literatura indianista, na pessoa de José de Alencar, e da recente produção literária indígena desde a condição e a questão indígenas. Interessantemente, há um pressuposto de fundo que demarca tanto a produção literária alencariana e, de resto, a própria literatura indianista do século XIX quanto à literatura propriamente indígena, a saber, a reflexão sobre o lugar, a imagem e o protagonismo do/a indígena em termos de constituição de nossa sociedade e de nossa identidade nacional, começando com a colonização e chegando-se à modernização conservadora que nos caracteriza e que dinamiza as potencialidades e as enormes contradiçốes presentes na sociedade brasileira. De fato, o/a indígena é o sujeito-objeto-tema central que embasa a colonização e que move, depois, juntamente com o/a negro/a, a abordagem em termos de formação da cultura nacional e de constituição de nosso processo de modernização. O/a indígena é a antítese da civilização, a barbárie-selvageria que precisa ser superada-domadaconduzida-formada pela civilização; ele, na sua condição antropológica e na sua forma de vida, é o empecilho à modernização, ao progresso, ao desenvolvimento; $\mathrm{e}$ o indígena é a massa amorfa que justifica o trabalho humanitário-civilizador assumido pelo branco, nas suas diferentes figuras históricas, do desbravador europeu ao sacerdote cristão, passando pelo bandeirante, pelo jesuíta, pelo senhor de engenho, pelo coronel, pelo militar nacionalista e chegando-se, enfim, ao empresário agrícola, figuras histórico-políticas elas mesmas justificadas nessa vocação civilizadora e modernizadora e, portanto, em sua orientação, em seu enquadramento e em seu etnocídio relativamente aos/às indígenas.

$\mathrm{O} / \mathrm{a}$ indígena, como dissemos, é o objeto que justifica a colonização e, depois, a modernização conservadora, como antítese a elas, como massa amorfa que permite a construção do novo mundo sonhado e buscado pelos desbravadores

${ }^{2}$ Kaká Werá. Coordenação de Sergio Cohn e de Idjahure Kadiwel. Rio de Janeiro: Azougue Editorial, 2017, Coleção Tembetá, pp. IOI-IO2. 
de ontem e de hoje. Nesse sentido, o indianismo, por meio da retomada desse duplo pressuposto que subjaz à e que justifica a colonização, aponta para o mito da fusão racial que está na base da ideia de uma pátria que se amalgama, que se funde em uma sopa indiferenciada de raças, culturas e formas de vida. Com efeito, se o indianismo começa com as contradições do contato, sustentando a desigualdade entre civilização e barbárie, entre branco e indígena, seu capítulo final é exatamente essa fusão voluntária, desejada e buscada pelo/a indígena e pelo branco/a, entre indígena e branco/a, de modo a fundar o híbrido brasileiro que, ao fusionar-se, apaga sua pertença indígena, joga para debaixo do tapete as contradições históricas e as diferenciações e os conflitos sociais entre colonizadores e colonizados. A partir da formação do híbrido, temos um novo começo, às custas da invisibilização e do silenciamento sobre o passado, isto é, às custas do genocídioetnocídio continuado, mas também despolitizado, sobre os povos indígenas e negros. Ora, esse é o núcleo da modernização conservadora brasileira, isto é, a naturalização da passagem da barbárie à civilização por meio do contato, que acaba recebendo um matiz civilizador, uma vocação de humanização do irmão menor pelo irmão maior, que benevolamente traz cultura, desenvolvimento, progresso, ilustração - ontem e hoje.

Na modernização conservadora, por conseguinte, parte-se de que essa vocação humanística, civilizacional e progressista encontra seu fecho de abóboda da fusão racial que apaga as diferenças e as contradições raciais, entre dominadores e dominados, iniciando um novo tempo, o tempo da igualdade, da reciprocidade, do reconhecimento e do benefício mútuo. Forma-se, com isso, a grande família Brasil, híbrida, totalmente indivisa, de identidade interna absoluta, hierarquicamente constituída e marcada por uma ordem apolítica-despolitizada para quem qualquer diferenciação leva a contradições intoleráveis que, por colocarem em xeque essa pátria familiar, devem ser enfrentadas a ferro e fogo. Com isso, a missão civilizadora e progressista do desbravador português, assumida hoje pelo empresário rural, pode ser despolitizada e naturalizada pela correlação de vocação civilizacional frente à barbárie indígena que, como massa amorfa, precisa ser formada e guiada, e de fusão racial que, ao consolidar-se, apaga a violência original, o estupro original que, ao contrário do consenso caricato e do voluntarismo falso, dá origem ao povo brasileiro - a violência, a negação e o estupro, a desterritorialização e o abandono, e não esse desejo recíproco (em especial do/a 
indígena em fazer-se branco, ou até do/a branco/a em doar caridosamente seu gene ao/à indígena), representam a matriz constituinte da cultura nacional, uma cultura de violência e de morte que, justificada normativamente, subjaz à retomada pujante de nossa modernização conservadora vivida hoje. Com base nisso, faremos uma intepretação da literatura indianista - mormente dos textos de José de Alencar - à luz da ideia de modernização conservadora como fusão racial apolítica-despolitizadora, que gera o híbrido brasileiro como negação do passado e purificação (por meio do silenciamento, da invisibilização, do esquecimento e da violência simbólico-material) do presente. A partir disso, ou seja, da enunciação do lugar do/a indígena pelo colonizador, traremos a literatura produzida recentemente pelos/as próprios/as escritores/as e intelectuais indígenas, com o objetivo de, por meio do lugar de fala agora indígena, percebermos o lugar, a imagem e o protagonismo do/a indígena dentro desse grande processo de formação da sociedade brasileira que vai da colonização à nossa modernização conservadora.

\section{I. $O$ indígena pelo colonizador: identidade nacional, mito da igualdade racial e a literatura brasileira do século XIX - o exemplo de José de Alencar}

A literatura indianista do século XIX é um dos pilares da construção normativosimbólica disso que entendemos por brasilidade, por identidade nacional, enquanto uma unidade de cultura e de espírito, não obstante a diversidade superficial (pois fazem parte, todos, da mesma grande família, na visão de nossa modernização conservadora) entre povos e perspectivas de mundo aqui presentes ou que para cá foram trazidos ou vieram ao longo da constituição de nossa sociedade, diversidade que é subsumida nessa visão de um grande Brasil que, como pai carinhoso e familiar, acolhe, protege e fomenta todos os seus filhos, sem prejuízos de raça, cor, religião e condição social. Esse Brasil já não seria mais um apêndice de Portugal, senão que entraria exatamente na rota da modernização e, na verdade, de uma modernização de tipo especial, uma vez que, aqui, como em nenhum outro lugar, a união e a integração entre raças e sua miscigenação gradativa, claro que sob o grande guarda-chuva normativo dado pelo modelo antropológico de cunho eurocêntrico, branco e cristão, seriam a tônica dessa nova nação, desse novo 
presente e futuro da humanidade, um exemplo sem igual quando observadas as demais sociedades. Ora, para a construção dessa identidade, o/a indígena foi utilizado como um modelo e um conteúdo fundamentais dessa nova nação e de seu futuro em aberto, que, se nos lembrarmos de Pero Vaz de Caminha e sua famosa carta à monarquia portuguesa quando do descobrimento, teria desde o inicio nos/as indígenas e nessa terra selvagens, mas ao mesmo tempo intocados/as, uma massa informe ou um papel em branco a ser moldado ou escrito de acordo com a visão do paraíso sustentada, representada e aplicada por seus missionários e com a mão forte do rei, um paraíso na terra, contra a degeneração do Velho Mundo.

Evidentemente, é um paraíso por construir, em termos de retirada de seu primitivismo, de sua barbárie e de sua selvageria, o que significa exatamente que ele precisaria ser conduzido por seu irmão maior, benevolente e, acima de tudo, detentor desse estágio maior de evolução, de progresso e de desenvolvimento que lhe capacitaria a orientar, a tomar pela mão - ou a usar a chibata ou a espada e a pólvora, quando necessário - ao seu irmão menor. Nesse sentido, o/a indígena é sempre a base para a construção de nossa identidade, e isso em um duplo sentido: ou é a antítese que justifica a superioridade do seu outro, do seu mestre, do colonizador, do europeu, branco e cristão, com seus valores civilizacionais; ou é a massa informe ou o papel em branco que deve ser trabalhado, moldado, orientado, conferindo missão, sentido e justificação ao trabalho missionário, integrativo e colonizador do europeu branco e cristão. Em ambos os casos, a nação se constrói e se compreende tendo como pano de fundo esse modelo de indígena como negação da civilização, como antítese da cultura e como massa de trabalho para o novo, para o futuro. É ele, o/a indígena, o material normativo que justifica a cultura nacional e que confere vocação às nossas instituições basilares. Ele é o estorvo ao progresso e o impeditivo da civilização (juntamente com o/a negro/a), mas também, como dissemos, é a massa informe na qual será impressa a marca da civilização, da cultura e do progresso, por isso mesmo dando sentido fundamental à visão do que somos e do que podemos e temos de fazer como sociedade familiar, orientada por laços de irmandade recíproca, de autoridade paternal centralizada, de ordem e de obediência cegas (afinal, que membro da família pode desobedecer a seu pai?!) e de identidade interna absoluta, sem cisóes, sem diferenciaçóes, sem 
contradições - ordem (familiar) para o progresso (como passagem da barbárieselvageria para a civilização, como integração indiferenciada e unidade absoluta). Ora, é também dentro desse contexto que gostaríamos de inserir a literatura indianista e sua proposta implícita de compreensão da identidade nacional nos moldes da grande família branca, transplantada para o conceito de uma pátria de grupos raciais-sociais irmanados, eles mesmos representando uma grande família de caráter macroestrutural e ligada a um modelo de ordem social paternalista, autoritária, escalonada e indivisa, sem rachaduras internas, plenamente integrada e indivisa (como o é a família tradicional, diga-se de passagem), miscigenada e, por isso, marcada pela fusão e pela integração de e entre as raças, mas uma integração que é sempre marcada pela superação do primitivismo e pela consolidação da civilização que o irmão maior vem humilde e prodigamente trazer ao irmão menor.

A literatura indianista, com efeito, recorreu ao “(...) mito de uma identidade indígena assimilada como pedra angular étnica da autoimagem cultural do Brasil”. de independência no fim do século XVIII e ao longo século XIX, situação de independência e de desenvolvimento que exigia uma imagem singular desse novo mundo e dessa nova gente. Essa imagem singular serviria como paradigma normativo da nossa autocompreensão nacional e como critério político-cultural para o enquadramento de seus grupos internos, mormente, em nosso caso nesse texto, os/as indígenas. Escritores como José de Alencar (I829-1877) e Gonçalves Dias (I823-I864) são referências do movimento romântico-indianista por celebrarem a “(...) viga mestra do projeto imperial de construção do Estado", |4 uma vez que enfatizam exatamente isso que salientamos mais acima enquanto arcabouço simbólico da nação brasileira, isso é,

I. o/a indígena como imagem básica da construção dessa nova identidade (como antítese e negação, como massa informe a ser moldada, que dá sentido à constituição e à vocação dessa nova sociedade),

${ }^{3}$ TREECE, Dave. Exilados, aliados, rebeldes: o movimento indianista, a política indigenista e o Estado-nação imperial. São Paulo: Nankin: Edusp, 2008, p. I2.

${ }^{4}$ Ibid., p. I3. 
2. a fusão racial desde uma perspectiva cordial, com a constituição de uma irmandade familiar plenamente amalgamada, sem contradições e diferenciações internas, altamente hierárquica, centralizada e ordeira, bem como

3. esse processo de transição da barbárie-selvageria para a civilização, em que $\mathrm{o} / \mathrm{a}$ indígena gradativamente se transformaria no seu grande irmão, o branco, o que também significa a sua anulação como indígena (como selvagem, como bárbaro) e a consolidação, afirmação e justificação do papel civilizacional do branco, sua missão neste novo mundo, que é orientar, conduzir, salvar o/a índio/a.

Paradoxalmente, mas por isso mesmo, o sujeito indígena foi tema, no século XIX, de romances, poemas, peças teatrais, pinturas e estudos etnográficos, vindo a corporificar "(...) aquele mesmo nacionalismo que se empenhava em levar a cabo sua própria aniquilação" 5 Esse/a indígena, portanto, era retratado como protonacionalista (no sentido de buscar a miscigenação, de aceitar passivamente a autoridade do branco e de seguir voluntariamente o caminho da cultura e da civilização, rompendo com sua condição pré-civilizacional), como irmanado com seu irmão branco e vinculado e comprometido com o processo de constituição de uma pátria nova, altiva (lembremos que, desde o século XVII, as guerras de libertação contra a Holanda no nordeste tiveram na imagem de Filipe Camarão o retrato caricato do índio aportuguesado que luta em prol da pátria de sangue e alma portugueses - esse mesmo Portugal das guerras justas do século XVI que, agora no século posterior, necessita dos índios e tem neles um aliado nacionalista). Como nos sugere Treece, foi esse mesmo suposto nacionalismo indígena calcado no fomento de uma visão patriota assumida pelos nativos que levou ao etnocídio daquele sujeito que serviu de base para sua autocompreensão normativa e de justificação para a missão civilizadora, missionária e messiânica do irmão branco, o/a índio/a - um nacionalismo que colocava e coloca a passagem da barbárie para a civilização, do arcaico para o moderno (ainda que seja uma modernização periférica e conservadora) como seu objetivo básico e que, por isso mesmo, engole, apaga, erradica o indígena, como sua grande antítese, como sua massa amorfa e,

s Ibid., p. I4. 
ao fim e ao cabo, como seu inimigo. O projeto de construção de uma imagem fundamental do "índio" $\sqrt{6}$ como símbolo nacional não correspondia, portanto, na prática, às políticas indigenistas ensejadas aos povos tradicionais, uma vez que, no Império (onde começa a se forjar essa ideia romantizada da pátria fundada no índio nacionalista), os povos indígenas sofreram um processo destrutivo de proporções genocidas, onde a depopulação consistiu no continuum desse movimento que vai da colonização ao Império: dos dez milhões de indígenas existentes no Brasil, no ano de I50o, passamos a cem mil indivíduos em fins do século XIX, quando cai o Império e emerge a República. A imagem romântica do "índio”, construída por nossa literatura do século XIX, enfatiza uma identidade étnica assimilada pacificamente, portanto totalmente fictícia, caricata e apolítica-despolitizadora, em vez de denunciar os processos colonizatórios sobre a cultura, o corpo e a alma indígenas. Como consequência do processo de modernização conservadora, é deixado de lado o reconhecimento da pluralidade cultural constituinte da nação brasileira e, principalmente, se despolitiza esse processo tenso de colonização, que passa a ser visto tanto como uma vocação de civilização quanto como um caminho sem volta que implica na integração do/a índio/a, isto é, em sua condução pelo irmão branco e em sua transformação em branco (na alma, pois no corpo a sua condição como diferença não pode ser apagada, tornando-se um estigma: nem totalmente branco, nem totalmente índio - um pária entre dois mundos). Segundo Daniel Munduruku (2017):

Nesse ponto, começou a construção do "índio" romantizado, que aparece nas literaturas de José de Alencar e de Gonçalves Dias, entre outros, e nos discursos políticos, obras artísticas e pesquisas científicas que passaram a retratar os nativos como seres de um passado exótico, guardados apenas na memória ruim da história nacional: 7

\footnotetext{
${ }^{6}$ Para o intelectual, escritor e ativista Daniel Munduruku, “(...) não existem índios no Brasil. Precisamos aprender como chamá-los, festejá-los, conhecê-los e, principalmente, valorizálos” (MUNDURUKU, Daniel. Sobre vivências, piolhos e afetos. Mundurukando 2. Lorena, SP: UK'A editorial, 20I7, p. 17). Para o autor, o termo "indígena” deve ser utilizado para o tratamento correto aos povos e sujeitos tradicionais, pois significa "nativo", "originário de um lugar”.

${ }^{7}$ MUNDURUKU, Daniel. Histórias de indio. Ilustrações Laurabeatriz. 2ª ed. São Paulo: Companhia das Letrinhas, 2016, p. 85.
} 
Com efeito, no romance histórico $O$ guarani, publicado originalmente em I857, José de Alencar retrata Peri, o personagem protagonista indígena, enquanto denotando características da nobreza medieval; nesse sentido, embora seja representado como homem honrado, com traços nobres de caráter, isto é, como um cavaleiro medieval, ao fim e ao cabo a tradição ameríndia e o cenário da natureza onde viviam os/as indígenas não são utilizados para exaltar a humanidade indígena, sua singularidade indígena, mas como forma de simbolizar que o/a índio é antítese e negação da condição eurocêntrica, como passo inferior relativamente a esta, de modo que aparece a valorização e a sublimação diretas e pungentes da tradição portuguesa e, como subsumindo a esta, da civilização ocidental em geral, com a consequente diminuição da cultura e do modelo antropológico indígenas. Entre alguns adjetivos que descrevem Peri, no texto de José de Alencar, estão "selvagem”, perro, caboclo, bugre, servo, escravo. Além disso, para despersonalizar o sujeito indígena, de Peri é retirado o orgulho do pertencimento étnico e o sentido da ancestralidade que estão para além da filiação à linhagem patriarcal de heróis guerreiros indígenas. Com efeito, relativamente a isso, tão logo o protagonista vê a imagem de Nossa Senhora, ele é subjugado por ela: “(...) 'Peri, guerreiro livre, tu és meu escravo; tu me seguirás por toda a parte, como a estrela grande acompanha o dia”", diz ela a Peri em um diálogo mudo e verticalizado..$^{8}$ Para justificar tal devoção, o autor, em nota de rodapé, acrescenta uma vivaz impressão de Peri pela imagem de Nossa Senhora, como se o primeiro contato do indígena como o colonizador subjugasse sujeitos e povos inferiores, em estado bárbaro, pela alvura da pele e pelo azul dos olhos, que fariam o mais acirrado selvagem humanizar-se pelo contato, com o contato, em termos de contato: “(...) Na casa da cruz, no meio do fogo, Peri tinha visto a senhora dos brancos; era alva como a filha da lua; era bela como a garça do rio" " psta é, em geral, a tônica do contato: a visão do branco, na sua cor alva, nos seus cabelos loiros, nos seus olhos azuis, desconcerta ao/à índio/a, levando-o/a ou à conversão como que direta, ou ao fascínio com esse seu irmão maior que, aos poucos, o conduzirá à conversão salvífica e beatificadora. Já à primeira vista o branco com sua brancura seduz; com suas palavras, conquista almas e corações.

\footnotetext{
${ }^{8}$ ALENCAR, José de. O guarani. 2 ed. Barueri, SP: Ciranda Cultural, 2017 [1857], p. Io5. 9 Id. Ibid.
} 
Nesse sentido, se o aparecimento do branco e o contato entre ele e o/a índio/a levam diretamente a uma conversão do/a índio ao modo de ser e de viver do branco, esse/a mesmo/a índio/a, por causa disso, também está pronto a negar sua pertença, sua tradição, sua ancestralidade - coisa que não ocorre com o branco. No que diz respeito a isso, Peri, o indígena goitacá, prontamente despreza a sabedoria dos antepassados ao ser assaltado no sonho pela imagem da Nossa Senhora que transforma o seu mais íntimo, reforçando a compreensão de que ele é um "bom selvagem”, esperando pela vinda da missão salvacionista disto que é a civilização, de que há "(...) uma ideia de bondade natural dos primitivos" que precisa ser atualizada pela civilização, pela brancura, pelo cristianismo $\mathrm{I}^{\mathrm{I}} \mathrm{De}$ igual modo, no romance Iracema, também de José de Alencar, publicado pela primeira vez em I865, a personagem principal, que é homônima do livro, Iracema, indígena do povo tabajara, é representada como se as referências tradicionais não fossem tão profundas quando a pertença portuguesa e religiosa do cristão Martim, reforçando a ideia já difundida no Tratado da terra do Brasil, de Pero de Magalhaes Gandavo, de I826, que dizia:

Não adorão cousa alguma nem têm pera si que ha na outra vida gloria pera os bons, e pena pera os maos, tudo cuidáo que se acaba nesta e que as almas fenecem com os corpos, e assi vivem bestialmente sem ter conta, nem peso, nem medida $]^{m}$

Em Iracema, o autor insiste na ideia de "bestialidade" ao representar o indígena Poti, do povo potiguara, a nação amiga do protagonista e português Martim Soares. As declarações de fidelidade, submissão e devoção são feitas por Poti a Martim, como se a amizade e a assunção da fé cristã fossem marcadamente superiores a ponto de nosso indígena abandonar sua tradição ancestral em um piscar de olhos, sem qualquer consideração:

${ }^{\text {Io }}$ BOSI, Alfredo. História concisa da literatura brasileira. 5I ed. São Paulo: Cultrix, 2017, p. IIO.

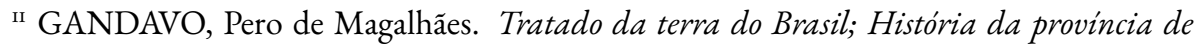
Santa Cruz. Belo Horizonte: Ed. Itatiaia. São Paulo: Ed. da Universidade de São Paulo, I98o [I826]), p. 54. 
Muitos guerreiros de sua raça acompanharam o chefe branco, para fundar com ele a mairi dos cristãos. Veio também um sacerdote de sua religião, de negras vestes, para plantar a cruz na terra selvagem. Poti foi o primeiro que ajoelhou aos pés do sagrado lenho; não sofria ele que nada mais o separasse de seu irmão branco. Deviam ter ambos um só deus, como tinham um só coração.

Ele recebeu com o batismo o nome do santo, cujo era o dia; e o do rei, a quem ia servir, e sobre os dois o seu, na língua dos novos irmãos. Sua fama cresceu e ainda hoje é orgulho da terra, onde ele primeiro viu a luz

Note-se, primeiramente, o termo "chefe branco", utilizado para qualificar a relação de (des)igualdade entre Martim e Poti. Este, como outros/as índios/as, seguem-no como líder, ele, que é o irmão maior desses pequenos. Note-se, em segundo lugar, a religião, que estabelece a cruz redentora em um lugar de selvageria e, com isso, o fato de que Poti se ajoelha humildemente, ele, um guerreiro que não se ajoelha diante de ninguém, à cultura maior representada pela tríade civilização, brancura e religião. Note-se, por fim e de modo mais importante, o mito fundador de nossa modernização conservadora, ou seja, que deve haver apenas um deus (uma só cultura) e um só coração (uma identidade indivisa), uma vez que a diferenciação e a heterogeneidade causariam contradição, causariam cisão, e Poti não quer, de forma alguma, separar-se de seu irmão - esta seria sua maior dor (embora ele tenha abandonado sua comunidade e entrado em conflito com os seus por amor do branco civilizado e cristão que, como seu irmão maior, lhe vem salvar). Aqui está, como vimos argumentando, o grande mito fundador da identidade brasileira, isto é, a identidade absoluta e a unidade perfeita, de cultura e de sangue, entre o/a índio/a e o branco (juntando-se depois o/a negro), de modo que a heterogeneidade, a diferenciação e a contradição devem ser negadas, eliminadas, pois causam dor, desintegração, instabilidade. A diferenciação, a heterogeneidade e a contradição não constroem, mas destroem - então, ordem e progresso.

\footnotetext{
${ }^{12}$ ALENCAR, José de. Iracema. Porto Alegre: L\&PM, 2017 [1865], p. II8.
} 
Embora a construção e a promoção da figura do/a "índio/a" sejam o elemento central no movimento indianista/nativista, é muito fácil identificar a tradição que segue José de Alencar em seu projeto literário. Em O guarani, em nota de rodapé, o autor explica o contexto ficcional em que se situa o enredo: “(...) Na ocasião da 'descoberta', o Brasil era povoado por nações pertencentes a uma grande raça, que conquistara o país havia muito tempo, e expulsara os dominadores" ${ }^{313}$ Essa nota de rodapé evoca a primeira invenção colonial sobre o Novo Mundo, o da "Descoberta" ou do "Descobrimento do Brasil". A partir dela, segue-se de modo direto e consequente a despolitização do projeto imperial de escravização de indígenas e, posteriormente, dos negros, em que se inverte os papéis de opressor e de vítima: em Oguarani, o fidalgo português, que assassina os povos “selvagens" para roubar as terras tradicionalmente habitadas pelos povos originários, utiliza a narrativa de que seriam eles, os colonizadores, aqueles que são efetivamente os atacados pelos “índios selvagens”, isto é, de que o colonizador é a vítima - qualquer semelhança com o que acontece na Amazônia e do centro-oeste, qualquer semelhança com o que diz nosso presidente Jair Messias Bolsonaro, isto é, de que não são os fazendeiros que derrubam a mata e póem fogo nela, mas os/as indígenas, e que estes prejudicam os fazendeiros que levam desenvolvimento a todos os rincóes do Brasil, não é mera coincidência. Representado como vítima dos "selvagens", ao português é redirecionado o olhar e a simpatia, onde o processo colonial lança motivos para justificar os assassinatos que, como forma de autodefesa, já não figuram historicamente como assassinatos e nem o colonizador como assassino, mas como legítima defesa. Diz Dom Antônio de Mariz, sobre isso: “(...) Para mim, os índios, quando nos atacam, são inimigos que devemos combater; quando nos respeitam são vassalos de uma terra que conquistamos, mas são homens!" ' ${ }^{14}$ São homens, mas devem ser mortos, se resistem, ou, se aceitam a submissão, são vassalos. A condição do homem indígena é definida como domesticado ou inimigo; jamais ao sujeito indígena é reconhecida a sua humanidade e, portanto, jamais lhe são atribuídas a igualdade e a reciprocidade que lhe são consequentes, se fosse um/a igual.

Como se pode notar, a invenção da narrativa da "descoberta", de "heróis" que vislumbram um Novo Mundo e se deparam com "selvagens”, “pagãos” e

${ }^{13}$ ALENCAR, José de. Oguarani. 2 ed. Barueri, SP: Ciranda Cultural, 2017 [1857], p. 7.

${ }^{14}$ Ibid., p. 38. 
povos sem civilização, destituídos de qualquer humanidade, que estão à espera de um redentor, é a linha de força que segue José de Alencar para dar constituição ao seu romance fundador e, de quebra, que serve como base normativa para a constituição de uma cultura nacional calcada, primeiro, no descobridor, segundo no bandeirante e, terceiro, no grande fazendeiro rural que desbrava os sertóes e a Amazônia, todos mediados pelo padre e, recentemente, pelo pastor. Diminuindo os povos tradicionais, no sentido de concebê-los em termos de protohumanidade, de proximidade com os animais mais do que com os humanos, e, com isso, distorcendo a imagem do protagonista Peri, o autor de $O$ guarani consolida imagens e identidades alienígenas aos povos indígenas, a partir de sua tradição ocidentalizada, justificando a separação entre barbárie-selvageria e civilização que confere ao modelo de homem europeu, branco e cristáo todo o protagonismo e ao/à índio/a toda a passividade e toda a permissividade.

Apesar de ser descrito como nobre, filho das florestas, tão logo quando fica diante dos portugueses, a quem é dada a alcunha de "seus senhores", a altivez de Peri se esvai: “(...) Apenas concluiu, a altivez do guerreiro desapareceu; ficou tímido e modesto; já não era mais do que um bárbaro em face de criaturas civilizadas, cuja superioridade de educação o seu instinto reconhecia" ${ }^{15}$ Ou seja, o próprio instinto, que o aproxima e o correlaciona com os demais animais e o distancia e o diferencia do homem civilizado (e só haveria homem civilizado), lhe mostra a superioridade do seu irmão maior, o branco. E esse instinto, que entre os seus iguais (os bárbaros, os selvagens, os animais) lhe torna feroz e homem de brio, diante do branco encolhe-o e subjuga-o naturalmente ao ponto de reconhecer o seu próprio superior na figura desse branco vindo de fora - e que, por vir de fora, por ser superior, vai salvá-lo, vai orientá-lo, vai dominá-lo (uma dominação legítima, pois conseguida por essa natural diferença e superioridade da civilização em relação à barbárie, da razão em relação ao instinto).

Outro exemplo que podemos elencar, nessa diferenciação feita por José de Alencar entre o/a índio e o branco, entre barbárie e civilização, é concomitantemente o fato de Isabel, filha bastarda do Fidalgo Dom Antonio de Mariz com uma indígena, odiar a Peri, porque este lhe lembra a identidade que ela quer negar, que

is Ibid., p. Io7. 
ela não quer ser, explícita, cristalina, com todos os estigmas que essa identidade decaida, inferior carrega, um estigma, uma chaga que não pode ser apagada (como é o caso das minorias político-culturais produzidas pela colonização - o ser negro, índio, gay ou até mulher não podem ser apagados, pois estão à luz do dia, no próprio aparecimento da diferença), o que também significa, por outro lado, que Peri, ao ver Ceci, que é branca e tem olhos azuis, nega a sua condição como índio/a, sua constituição como índio/a, considerando-se exatamente inferior, mostrando que o verdadeiro padrão referencial de beleza - e de sabedoria e de postura moral - é o branco de olhos azuis: ao ver-se diante desse corpo branco e de olhos azuis, sua inferioridade como indígena se torna explícita, ele toma consciência dela, instintivamente.

Ceci, de modo exótico, diz a Isabel que tem inveja do seu (de Isabel) tom moreno de pele, ao passo que esta responde, aplicando o estereótipo básico que vai marcar permanentemente a condição desse filho de dois mundos, o mestiço, nem índio (não se aceita como tal, não é aceito como tal), nem branco (quer sê-lo, mas não pode; não é aceito pelo branco como tal): “(...) - E eu daria minha vida para ter a tua alvura, Cecília" ${ }^{16}$ Além disso, o estopim que culmina no conflito central da obra, em que os aimorés, descritos como ferozes, "selvagens" e "canibais", atacam a casa/forte do fidalgo, a morte de uma mulher aimoré, é desprezado, minimizado, afirmado como sem importância, exatamente pela condição da vítima como mulher indígena, conforme se pode ver nas palavras de D. Lauriana, a matriarca da família: “(...) - Mas é preciso ver que casta de mulher é esta, uma selvagem...”. ${ }^{17}$ Por ser selvagem, sua morte não precisaria nem ser investigada, nem punida! Em outro momento, sobre a possibilidade de se livrar de Peri, a matriarca repete seu raciocínio: “(...) Sem dúvida: essa casta de gente, que nem gente é, só pode viver bem nos matos” ${ }^{18}$ A civilização, aqui, seria algo distante da realidade indígena, como antítese dela, na verdade. Por isso, estariam fadados à animalidade ou sua morte não causaria comoção e nem necessidade de reparação.

Essa noção de animalidade, de bestialidade e de ferocidade, aliás, é outro ponto que merece ser salientado como uma das tônicas da obra de Alencar, $O$

\footnotetext{
${ }^{16}$ Ibid., p. 36.

${ }^{17}$ Ibid., p. 38.

${ }^{18}$ Ibid., p. 75 .
} 
guarani. Com efeito, dos aimorés aparece, incrivelmente na boca de Peri, a seguinte imagem: "Ora, o índio conhecia a ferocidade desse povo sem pátria e sem religião, que se alimentava de carne bumana e vivia como feras, no chão e pelas grutas e cavernas" 19 Este pensamento é retratado por Peri, o indígena goitacá, mas ele representa um dos núcleos centrais construídos e sedimentados pelos colonizadores, podendo ser visto inclusive na Carta de Pero Vaz de Caminha, com mais ou menos intensidade: índios/as não têm pátria, não têm religião e não têm cultura; comem carne humana e dormem em buracos no chão. São, portanto, como animais. E esta imagem aparece, em $O$ guarani, na boca do próprio Peri, que, ao se diferenciar dos aimorés, aumenta e justifica o abismo entre os indígenas identificados pelos colonizadores como "domesticados" e aqueles concebidos como "selvagens bárbaros". Esta mesma ideia é repetida durante o desenrolar do romance, especialmente durante o ataque dos indígenas aimorés ao fidalgo Dom Antonio de Mariz. Sobre o ataque, aparece a seguinte descrição por José de Alencar:

Enquanto se ocupavam com esse trabalho, um prazer feroz animava todas essas fisionomias sinistras, nas quais a braveza, a ignorância e os instintos carniceiros tinham quase de todo apagado o cunho da raça humana ${ }^{20}$

Destituídos de cultura e de civilização, são apenas bárbaros, comedores de carne humana, possuidores de comportamentos animais e, em tudo isso, são antítese da civilização, uma vez que não têm deus, governo e nem cultura. Com isso, no texto, o índio "bom” é aquele domesticado, mas então já não seria mais índio; e o mau é o indígena bravio, incapaz de aprendizado cultural e moral. Em outras palavras, o povo indígena "bom", "domesticado", "servil" e "devoto" é aquele que já não existe na história, porque foi destruído. O outro, o "feroz", o "selvagem", o "irracional”, é aquele vivo, os aimorés, no caso do texto, que se apresentam como barreira à empresa colonial e sua função civilizadora. Nem se falaria mais, aqui, em troncos linguísticos ou em comunidades étnicas, mas pura

\footnotetext{
${ }^{19}$ Ibid., p. 83, os destaques são nossos.

${ }^{20}$ Ibid., p. 247.
} 
e simplesmente em indios domesticados e indios selvagens. Conforme Cunha, os indígenas são subdivididos, no século XIX, em "bravos" e "domésticos ou mansos”, onde os bravos são os tapuias, os indígenas vivos, “(...) aqueles contra quem se guerreia por excelência nas primeiras décadas do século: sua reputação é de indomável ferocidade" ${ }^{21} \mathrm{E}$ os "domésticos ou mansos" são aqueles que são vistos pelos colonizadores como já sedentarizados nos aldeamentos, vivendo sob o "suave jugo das leis", gradativamente aculturados, cristianizados e submetidos a um regime de trabalho dinamizado pela fazenda rural ou por atividades liberais básicas. Esse índio amansado, entretanto, é uma ficção, porque simplesmente foi erradicado da face da Terra pelo próprio colonizador que aparentemente quer the trazer a civilização, quer lhe levar à civilização. A autora assinala, relativamente a isso, que:

Há, primeiro, os Tupi e os Guarani, já então virtualmente ou extintos, ou supostamente assimilados, que figuram por excelência na imagem que o Brasil faz de si mesmo. É o índio que aparece como emblema da nova nação em todos os monumentos, alegorias e caricaturas. É o caboclo nacionalista da Bahia, é o índio do romantismo na literatura e na pintura. É o índio bom e, convenientemente, é o índio morto 22

\section{Identidade nacional como fusão-conciliação racial: unidade absoluta, ausência de diferenciação, negação das contradições internas - sobre a grande família Brasil vista pelo prisma da literatura indígena}

A identidade social, cultural e normativa da pátria Brasil é concebida e afirmada, no contexto de nossa modernização conservadora, em termos de fusão racial, demarcada por um contato que, se, por um lado, leva ao embate entre

${ }^{21}$ CUNHA, Manuela Carneiro da. Índios no Brasil: história, direitos e cidadania. I⿳亠丷厂 ed. São Paulo: Claro Enigma, 20I2, p. 62.

${ }^{22}$ Ibid., p. 62. Cf. ainda BOSI, Alfredo. História concisa da literatura brasileira. sI ed. São Paulo: Cultrix, 2017, p. I05. 
barbárie-selvageria e civilização, por outro lado, é resolvido sob a forma da consolidação gradativa, e definitiva, de uma identidade interna absoluta em que as raças desaparecem para dar lugar ao homem novo, o híbrido: temos no nosso sangue todas as raças e, portanto, somos todas elas ao mesmo tempo. A diferença entre oprimidos e opressores, entre colonizados e colonizadores, se esvai e, com ela, o poder do lugar de fala, o poder da crítica social e do ativismo político vindo dos marginalizados: somos todos engolidos e misturados nessa sopa insossa do caldeirão Brasil. Forma-se, por isso mesmo, uma pátria que pode ser descrita como uma grande família indivisa, sem contradições e fraturas internas, com integração absoluta, em que não há heterogeneidade, diferenciação e contradições, vistas como negativas. Constituímos, com a fusão racial, o novo mundo ansiado, com uma sinergia, uma identidade e um fim social comuns, uniformes, em que temos sangue comum e conciliamos, nessa identidade híbrida de caráter apolíticodespolitizado, todas as nossas diferenças, apagando-as. Como consequência, a violência não é mais que um fato histórico já realizado, passado pura e simplesmente; e, no mesmo diapasão, a práxis reparatória perde legitimidade, porque, afinal, não existe nem opressor nem oprimido - estes já ficaram também no passado e hoje todos temos as mesmas condições, os mesmos direitos e a mesma responsabilidade pelo mérito ou pelo demérito em termos de nosso status quo.

Com efeito, o lance final e fecho de abóboda da formação de nossa identidade nacional como híbrido apolítico, como amálgama absoluto, síntese do contato como fusão racial, como gênese do híbrido que é o brasileiro, apresentados pelos romances de Alencar, mormente O guarani Iracema, apontam exatamente para isso: a união umbilical entre o inferior, o/a índio/a, e o superior, o branco, que leva à geração do homem novo e, portanto, da nova pátria, esse híbrido de que falamos acima. Com essa fusão, acabou a brancura, acabou o tom moreno e, mais adiante, acabará a cor negra, pois somos todos filhos da mesma pátria, contendo em nosso DNA o sangue de todos esses povos agora fundidos e, na nossa cultura, a síntese das três raças fundadoras, matrizes do híbrido apolítico-despolitizado, marcado pela igualdade e pela integração absolutas. Por isso, qualquer diferenciação, ao tender inevitavelmente à destruição de nossa unidade familiar, torna-se ilegítima e pode ser destruída por todos os meios. O romance $O$ guarani, nesse sentido, se encerra com a cena em que Peri carrega Ceci em seus braços, apontando exatamente para a constituição da grande família Brasil que advirá da união 
de corpo e de alma de duas raças que em tudo são como água e azeite, mas que, ao se fundirem, apagarão essa diferença constitutiva, tornando-se uma só, híbrida; e, em Iracema, a protagonista “(...) morre depois de dar à luz ao filho, que será mestiço, portanto, Moacir (filho do sofrimento, no tupi de Alencar), cujo pai é o português Martim" ${ }^{23}$ Nesse último caso, o que estava pressuposto em Peri e Ceci, isto é, a fusão racial que dá origem à grande família Brasil, aparece agora com todas as letras: o Brasil surgiu não do estupro, não da violência do branco para com o/a indígena e o/a negro, mas da relação consentida, da união desejada, do amálgama de corpo e de alma, de identidade e de cultura, da admiração recíproca e do desejo comum de se fundirem em uma só carne e em um só espírito, por meio da geração do híbrido brasileiro, que resume e subsume em si nossas raças fundadoras e seu amor e desejo recíprocos. As duas obras ficcionais, para Sá, determinam o padrão racial do país, justificando uma miscigenação supostamente pacífica entre os dois povos que, por isso mesmo, não apenas não gera dívidas históricas e a necessidade de reconhecimento e de reparação pelo etnocídio indígena e pela escravização do/a negro/a, senão que pode ser esquecida, pois que reside em um passado distante de todos nós, já superado por essa fusão racial que une de corpo e alma, em identidade e cultura as três raças constituintes de nossa sociedade, tornando-nos híbridos de todas elas, retirando qualquer sentido de culpa, de divisão e de diferenciação entre oprimidos e opressores. Como diz Rosa, sobre essa questão de uma fusão racial que, ao criar o híbrido brasileiro, (a) apaga as diferenciaçôes e as contradiçóes de nosso processo civilizacional, (b) elimina a noção de lugar de fala, ao negar a contraposição entre opressores e oprimidos e (c) despolitiza os processos históricos e os sujeitos constituintes de nossa sociedade, além de implicar na recusa de uma práxis reparatória, inclusive insistindo-se na ideia de que o/a indígena é a antítese do progresso:

Tal imagem resplandece em toda política indigenista do século XIX até nossos dias, a saber, em que, passadas as agruras do "parto" colonial, há uma espécie de imperativo (i)moral para a nova nação que surge: seguir em frente para um futuro sem culpa por meio da

${ }^{23}$ SÁ, Lúcia. Literaturas da floresta: textos amazônicos e cultura latino-americana. Rio de Janeiro: EdUERJ, 20I2, p. I86. 
negação de uma história genocida (e talvez, por isso mesmo, sem perdão) e que reserva aos indígenas (e de certa forma a todos os não-europeus) a celebração de um passado mítico, que foi lido por não-índios, e uma posiçã̃o de exclusão no cenário nacional. ${ }^{24}$

A fundação normativa da nação, nesse sentido, conforme assinala OlivieriGodet é “(...) baseada na figuração de um território integrador, pacificado e unido, no qual evoluem as três principais matrizes étnicas, cujas relaçôes são descritas segundo uma ótica que 'naturaliza' o processo de mestiçagem". ${ }^{25} \mathrm{~A}$ naturalização e, portanto, a apoliticidade-despolitização desse processo, no entanto, transformam em um evento casual, não planejado e não desejado pelo colonizador o assassinato planificado e a negação e a estigmatização normativas dos povos indígenas e negros, bem como em um nada político e em uma ausência de significado histórico-normativo o lugar e o papel dos/as indígenas e dos/as negros/as em nossa história nacional. Nessa visão mistificada de nossa identidade nacional, assumida em cheio por nossa modernização conservadora, os/as indígenas representam um passo evolutivo anterior à civilização, à modernização, que precisam ser guiados gradativamente para ela e por ela e, no caso, o etnocídio foi um acidente, nunca algo planejado - em ambos os casos, entretanto, como antítese da civilização e como acidente não planejado, tiveram sua imagem deturpada e deslegitimada estética e culturalmente, sendo silenciados e invisibilizados politicamente. Ora, é nesse contexto que emerge a literatura indígena brasileira como voz-práxis estético-política, especialmente a partir da década de 1990, na esteira e como sustentáculo do Movimento Indígena brasileiro que se consolida desde meados da década de 1970 como reação aos processos de desterritorialização e de violência simbólico-material sofridos pelos povos indígenas no contexto da expansão agropecuária para o centro-oeste e o norte do Brasil, promovida pelos governos militares. Se o Movimento Indígena, em figuras como Álvaro Tukano,

${ }^{24}$ ROSA, Francys Mary Soares Correia da. "Representações do indígena na literatura brasileira”. In: DORRICO, Julie; DANNER, Leno Francisco; CORREIA, Heloisa Helena Siqueira; DANNER, Fernando. Literatura indigena brasileira contemporânea: criação, crítica e recepção. Porto Alegre, RS: Editora Fi, 2018, pp. 257-293; p. 277.

${ }^{25}$ OLIVIERI-GODET, Rita. A alteridade amerindia na ficção contemporânea das Américas: Brasil, Argentina, Quebec. Belo Horizonte, MG: Fino Traço, 2013, p. I5. 
Marcos Terena, Carlos Estevão Taukane, Eliane Potiguara, Manuel Fernandes Moura, Mário Juruna, Raoni Metuktire e Ailton Krenak etc., busca superar a correlação de menoridade relativa, paternalismo institucional e de despolitização do sujeito indígena por meio de uma voz-práxis direta, autônoma e militante, os/as escritores/as indígenas, na esteira dele, utilizam-se exatamente da voz-práxis estético-literária como arma política de enquadramento, de crítica e de diálogo para com a sociedade envolvente. Para começar, portanto, o primeiro aspecto central da literatura indígena brasileira, da voz-práxis estético-literária produzida e dinamizada pelos indígenas, consiste exatamente no seu sentido político, como crítica do presente. Sobre essa intenção fundadora e dinamizadora da literatura indígena, nos fala Kaká Werá:

Para nós, a literatura indígena é uma maneira de usar a arte, a caneta, como estratégia de luta política. É uma ferramenta de luta. E por que uma luta política? Porque, à medida que a gente chega na sociedade e a sociedade nos reconhece como fazedores de cultura, como portadores de saberes ancestrais e culturais, ela vai reconhecer que também existe uma cidadania indigena. ${ }^{26}$

Ora, qual o significado da literatura, da arte como voz-práxis política e politizante? Qual sua intenção? Exatamente a constituição de uma voz-práxis direta, ativista, militante e engajada em torno à condição e à causa indígenas. Trata-se de $\mathrm{o} / \mathrm{a}$ indígena falar por si mesmo/a e desde si mesmo/a, consolidando sua autonomia e sua cidadania políticas. Note-se, na passagem acima, que é a consolidação da cidadania política que é vista como o passo e o caminho fundamentais para a resistência dos e pelos povos indígenas contra processos de violência simbólicomaterial e de desterritorialização que ainda hoje mantêm força social, política e institucional, ameaçando permanentemente sua integridade - posto que nunca foram enfrentados consistentemente pelas nossas instituições e pelos nossos sujeitos sociais. Nesse sentido, seu ativismo e seu enraizamento na esfera pública, como sujeitos político-culturais, são a base, a atitude e o instrumento fundamentais para

${ }^{26}$ WERÁ, Kaká. Kaká Werá. Coordenação de Sergio Cohn e de Idjahure Kadiwel. Rio de Janeiro: Azougue Editorial, 2017 (Coleção Tembetá), p. 29, os destaques são de Kaká. 
o enfrentamento dessa perspectiva institucional, política, cultural e econômica de permanente ameaça à integridade simbólico-material dos povos indígenas. E é um enfrentamento que necessita de visibilização, de contestação e de ativismo, posto que quem não aparece na esfera pública não existe politicamente. Este, aliás, é o grande ensinamento e a atitude fundamental das minorias político-culturais que superam gradativamente o silenciamento, a invisibilização e o privatismo aos quais foram tradicionalmente empurradas pela afirmação dessa postura ativista, militante e engajada de que estamos falando. Afinal, as únicas coisas e os únicos sujeitos que devem ficar dentro do armário são o fascismo, o fundamentalismo e o racismo. Ao consolidarem-se publicamente, como sujeitos político-culturais, as minorias permitem a pluralização dos sujeitos, das histórias, das práticas, dos valores e dos símbolos constituintes de nossa sociedade e, assim, instauram efetivamente crítica social, práxis reparatória, reconhecimento cultural, inclusão social e ativismo político, que somente são detonados pela pluralidade e como pluralidade. O segredo é sempre a cidadania política, a práxis política das e pelas diferenças. É assim que a voz-práxis literária como ativismo estético-político, como instrumento político, permite o aparecimento e a consolidação dos/as indígenas (ou das minorias) na esfera pública e como sujeitos político-culturais, ou seja, possibilita uma fala-práxis direta, sem mediações, a partir da própria condição, das experiências e das tradições específicas às minorias, aos povos indígenas. Mais uma vez é Kaká Werá quem nos fala, relativamente à emergência da literatura indígena:

Naquela mesma época, em nossos encontros na aldeia guarani, eu conversava muito com o Daniel Munduruku. Ele já era um educador, formado em filosofia, e dava aula em escola pública. A gente conversava muito sobre como encontrar maneiras de potencializar esse trabalho de difusão. E tanto ele quanto eu gostávamos muito de literatura. Eu já estava ensaiando meus primeiros escritos literários. Então nós sonhamos, naquela época não era ainda criar um movimento de literatura indígena, mas em usar a escrita para falar das nossas culturas. Para falar diretamente. Para se ter uma ideia, até o início dos anos 1990, o que se tem notícia é de que praticamente tudo o que existe de escrito no Brasil sobre o índio, sobre os povos 
indígenas, sobre as culturas indígenas, não foi escrito por um índio. Foi sempre por um indigenista, por um antropólogo, por um sociólogo, por um estudioso, por um artista, por um poeta, por um escritor. Não que eu ache que isso seja uma coisa errada. Mas eu achava que, na medida em que nós nos tornássemos protagonistas de nossas próprias vozes, isso poderia gerar uma força muito grande, uma estratégia muito potente para se comunicar diretamente com a sociedade. E também para a sociedade ouvir diretamente a voz de um intelectual, de um cidadão, de um pensador, de um curador, de um contador de histórias vindo de um povo indígena ${ }^{27}$

Munido/a dessa fala-práxis direta, o/a indígena pode expressar-se desde sua condição e trazer-nos as experiências próprias à sua singularidade, o que coloca as minorias como sujeitos, condição e valor insubstituíveis e irrepresentáveis em uma sociedade democrática, condição fundamental para a correção e a reconstrução de nossas instituições, de nossos processos de socialização e para a reparação pelos crimes da colonização, do etnocídio indígena, da escravização negra, da homofobia, da transfobia e do feminicídio etc. Com efeito, as minorias político-culturais foram e são produzidas em termos simbólico-normativos a partir de um duplo pressuposto: são um estigma, uma chaga, uma anormalidade e uma imoralidade, ou até uma condição arcaica, que precisam, por conseguinte, ser superadas, guiadas, curadas e até combatidas; e, por isso mesmo, são submetidas pelo colonizador a processos de violência, de negação e de deslegitimação simbólico-material que produzem o sujeito-grupo pária, o grande mal a ser enfrentado, silenciado, invisibilizado, e, em todos os casos, levam ao seu assassinado direto. Nesse sentido, as minorias carregam na sua cultura e no seu corpo a própria violência simbólicomaterial etnocida, a própria história de violência que constitui a raiz fundamental da constituição de nossa sociedade. Elas não apenas não podem esconder isso, de si e dos outros; seu aparecimento da esfera pública também traz à luz do dia e, assim, desnaturaliza e politiza a violência colonial, a miséria, a marginalização e a exclusão que são o resultado dessa violência colonial. Por isso, mais uma vez, a ideia de uma fala-práxis direta, que motiva o desenvolvimento da literatura

${ }^{27}$ Ibid., pp. 25-26. 
indígena brasileira (assim como a literatura e o ativismo das minorias de um modo geral) traz para o centro da vida social e em termos de politização radical, os sujeitos marginalizados, as fraturas, as contradições, os mitos fundadores mal justificados e, em tudo isso, as vozes, as experiências, as histórias alternativas de nossos grupos constituintes. Esta, aliás, é a provocação que Eliane Potiguara nos lança em Metade cara, metade máscara, especificamente em seu poema Brasil:

Que faço com minha cara de índia?

E meus cabelos

E minhas rugas

E minha história

E meus segredos?

Que faço com minha cara de índia?

E meus espíritos

E minha força

E meu tupã

E meus círculos

Que faço com minha cara de índia?

E meu toré

E meu sagrado

E meus "cabocos"

E minha terra?

Que faço com minha cara de índia?

E meu sangue

E minha luta

E minha consciência

E meus filhos?

Brasil, o que faço com minha cara de índia?

Não sou violência

Ou estupro 
Eu sou história

Eu sou cunhã

Barriga brasileira

Ventre sagrado

Povo brasileiro.

Ventre que gerou

O povo brasileiro

Hoje está só...

A barriga da mãe fecunda

E os cânticos que outrora cantavam

Hoje são gritos de guerra

Contra o massacre imundo 28

Note-se, aqui, a pluralização das histórias, das vozes, das experiências e dos valores no que tange à interpretação de nossa sociedade e, dentro dela, do que foi o processo de colonização, do que é nosso processo de modernização conservadora. Este, a pluralização dos sujeitos e das histórias de formação de nossa sociedade, com a consequente desnaturalização e politização desse mesmo processo, em verdade, é o segundo ponto importante da literatura indígena brasileira, consequência deste primeiro ponto que chamamos a atenção acima, ou seja, o ativismo político assumido por ela sob a forma da constituição e da dinamização de uma voz-práxis direta que se funda nas experiências de marginalização como diferença, como minoria, vividas e, assim, publicizadas pelos/as próprios/as indígenas. Nesse sentido, $\mathrm{o} / \mathrm{a}$ indígena tem condiçóes de nos narrar na correlação de primeira e de terceira pessoas do singular - eu-nós - experiências e interpretações vividas como minoria simbólico-material. Como fizemos ver na primeira parte desse texto, o/a indígena foi o grande objeto da colonização, como antítese dela e como massa informe a ser moldada - ou seja, apagada como singularidade - para a consecução de um novo mundo, de uma sociedade civilizada, desenvolvida e

${ }^{28}$ POTIGUARA, Eliane. Metade cara, metade máscara. Lorena: UK'A Editorial, 20I8, pp. 29-30. 
modernizada. Como objeto desse processo histórico de violência simbólica, política, cultural e material, a visão e a avaliação que o/a indígena nos faz da formação de nossa sociedade é bem diferente da visão e da versão oficiais, de uma fusão racial absoluta e de uma evolução pacífica, voluntária e integradora. Perguntado sobre o significado dos 500 anos de história brasileira para os/as indígenas, Ailton Krenak nos diz:

Esses 500 anos da chegada dos barcos na praia significam uma terrível guerra de extermínio contra o nosso povo. Não significam de jeito nenhum uma boa nova. Nós éramos 900 tribos só aqui neste pedaço que hoje chamam de Brasil. Do século XVI até o final do século $\mathrm{XX}$, nós fomos reduzidos a I8o tribos; 720 grupos étnicos foram passados ao fio da espada, da doença, da violência, da brutalidade, da desagregação social e cultural. Nós fomos reduzidos a um grãozinho de areia, e nós éramos milhares aqui neste lugar. Nestas terras, nossos povos viviam, educavam seus filhos, caçavam, pescavam, praticavam suas religióes, suas tradições, seus cultos, suas vidas. Nós éramos povos muito particulares, porque nós éramos constituídos de pequenos grupos tribais. As nossas convençốes sociais são vistas hoje como coisa muito simples e primitiva, mas elas eram suficientes para nos manter felizes, para nos manter vivos e garantir que nós não destruíssemos uns aos outros. (...) Então, eu acredito que esses 500 anos de contato com os brancos, em que o nosso povo tentou pacificar o branco, tentou dizer para o branco que é possível viver de uma outra maneira, foram anos de muita dificuldade, de muita morte. Eu não saberia contar quantas pessoas indígenas foram mortas nesses 500 anos. Nós éramos aproximadamente Io milhóes de pessoas que vivíamos aqui neste lugar que é a costa do Atlântico até a parte mais central que eles chamam hoje de Brasil. Nisto que eles chamam de costa brasileira havia dezenas e dezenas de aldeias. Nós éramos io milhões quando chegaram apenas três canoas com os brancos dentro delas. Hoje, somos 220 mil pessoas e os brancos são 
I30 milhôes. O que a gente pode concluir de uma história dessas? Foi bom para o nosso povo: ${ }^{29}$

Note-se a potência crítica do lugar de fala das minorias. No mesmo diapasão, note-se o empoderamento e o significado políticos proporcionados pelas experiências de marginalização que nos são contadas pelas próprias vítimas da colonização. É por isso que dissemos, acima, que a voz-práxis direta das vítimas, das minorias, é irrepresentável politicamente e, do mesmo modo, constitui-se em condição política sine qua non para a maturação crítica e a reconstrução sociocultural e político-institucional de nossa sociedade, de nossa história. A voz-práxis direta, a fala-práxis direta, dos/as marginalizados/as por si mesmos/as e desde si mesmos/as, permite exatamente visibilizar, desnaturalizar e politizar o processo contraditório de construção dessa grande família fundida-amalgamada racialmente, indivisa e de identidade plena, hierárquica e erradicada de contradiçôes internas. Na visão do senhor de engenho, transplantada para o modelo militarista-aristocrático de agrobussines, para quem a violência é sempre causada pelos outros, que emperram o progresso, a modernização e a civilização, diferenciações e contradiçóes impedem que se consolide uma visão unívoca e massificada necessária para a estabilidade social. É por isso que a ordem e o progresso andam juntos, ou seja, a integração absoluta e a despolitização geral, a partir do esquecimento da história, do apagamento das diferenças sociais e da recusa da práxis crítico-reparatória em relação ao passado, são condiçôes para a implantação de um processo de crescimento econômico que, ainda hoje, vê na derrubada da floresta, na tomada das terras indígenas e, ao fim e ao cabo, na modernização do/a indígena (que, na boca de nosso presidente, Jair Messias Bolsonaro, não quer viver como animal enjaulado em uma reserva - sem sequer ter ouvido o que os/as indígenas têm a lhe dizer). Por isso mesmo, na visão tradicional de nossa modernização conservadora, só o empresário rural - herdeiro do senhor de engenho, dono de escravos e coronel político - é que pode e deve falar publicamente, pode e tem condições de decidir acerca do caminho e dos fins do processo de evolução social. O aparecimento das minorias na esfera pública e a constituição e a dinamização de sua fala-práxis,

${ }^{29}$ KRENAK, Ailton. Encontros. Organização de Sérgio Cohn. Rio de Janeiro: Azougue Editorial, 2015, pp. 156-I57, os grifos são nossos. 
de modo direto, carnal e vinculado, póem em xeque essa condição de autoritarismo político e, por consequência, explicitam os processos contraditórios que nos constituem como sociedade plural, de homogeneização forçada. Diz ainda Ailton Krenak:

O que eu acho é que muitas pessoas aqui estão incomodadas com que o mundo veja o Brasil na cara do Raoni (Metuktire). Porque o sinhozinho estava na sala tomando café, quando soube que alguém fugiu da senzala e foi fazer algazarra. Ficou apavorado, chamou o capataz e perguntou: "mas o que é isso? Fugiu um negro da senzala; foi fazer confusão aí no mundo”. Quem pode mostrar a cara lá fora é o sinhozinho. Ele sai da sala com gravata e paletó e vai se exibir no paraíso. Agora, pessoal da senzala, das malocas, não pode sair por aí se exibindo de tanga, botoque e cocar. O incômodo é tão grande para uma parte da elite brasileira que é mais ou menos como se vocês estivessem exibindo um segredo de família para o público. O Brasil está vendendo o retrato do branco para o mundo há 500 anos. De repente, quando ele mostra o pessoal que não é branco... ${ }^{30}$

As minorias, os povos indígenas exibindo um segredo de família ao público, ao aparecerem a esse mesmo público! Segredo de família: exatamente o grande núcleo de nossa modernização conservadora, em que a violência simbólico-material é escondida, varrida para debaixo do tapete e despolitizada, negada até, de modo a não existir nem diferenciações, nem contradições, nem desigualdades, nem párias do processo civilizacional. É contra essa perspectiva de negação, de silenciamento e de despolitização, não apenas do passado, mas do próprio presente, que o ativismo estético-literário dos/as e pelos/as intelectuais indígenas encontra seu sentido e se rebela; é contra essa situação de apoliticidade-despolitização de um processo complexo, que teve na violência e na produção de minorias políticoculturais seu núcleo e sua dinâmica centrais, levando à formação de uma sociedade massificada para a qual essas minorias nunca sequer existiriam (e, por isso, não têm nada a cobrar, a exigir, e nada e nem ninguém por quem lutar), é contra

\footnotetext{
${ }^{30}$ Ibid., p. 96.
} 
essa situação de apoliticidade-despolitização, como dizíamos, que a constituição de uma fala-práxis direta, política e politizante, carnal e vinculada, encontra seu sentido e sua potência. E esse sentido e essa potência da voz-práxis indígena também podem ser percebidos em uma das passagens acima, de Ailton Krenak, quando ele afirma que os povos indígenas, nesses mais de 500 anos de descoberta do Brasil, tentaram, por meio do contato, pacificar, amansar o branco. Note-se, nessa afirmação, que a história do encontro, contada pelo sujeito marginalizado, silenciado e invisibilizado, é exatamente o contrário da história oficial mistificada e projetada pelos nossos sujeitos modelares da constituição de nossa sociedade: o desbravador português, o missionário cristão, o bandeirante paulista, o imigrante europeu, o militar nacionalista, o senhor de engenho, o empresário rural. Para esses, a história nacional se constitui como um processo de civilização, como uma missão humanitária que faz a passagem da barbárie-selvageria para a civilização, das trevas para a luz, do índio para o europeu. Aqui, o protagonismo é do modelo de homem europeu, branco, cristão, militar e empresário - esses qualificativos reunidos em geral todos na mesma pessoa. Ao índio resta apenas a aceitação voluntarista, quando impressionado pela grandiosidade do branco, conforme vimos em José de Alencar, ou sua domesticação forçada, ou até o seu assassínio, que também vimos no referido autor. Contrariamente a isso, a história contada pelas minorias, as experiências trazidas por ela nos mostram exatamente uma postura de resistência, de ativismo e de interatividade que explicitam o grau de emancipação, desenvolvimento e potência crítica do/a e pelo/a indígena. Assim é que novamente Ailton Krenak sintetiza sua perspectiva militante como liderança e intelectual indígena, em torno ao movimento indígena, como uma práxis desconstrutiva-construtiva relativamente a esse imaginário tradicional, naturalizado, apolítico-despolitizado sobre o indígena. Ele diz, sobre o sentido de seu engajamento político-cultural:

E o outro desconforto era me identificar como índio, porque índio é um erro de português, plagiando o Oswald, que disse que, quando o português chegou no Brasil, estava uma baita chuva, aí ele vestiu o índio, mas, se estivesse num dia de sol, o índio teria vestido o português, e estaria todo mundo andando pelado por aí. Isso continua valendo até hoje, e eu atualizei dizendo que o índio é um equívoco 
do português, não um erro, porque o português saiu para ir para a Índia. Mas ele perdeu a pista e veio bater aqui nas terras tropicais de Pindorama, viu os transeuntes da praia e acabou carimbando de índios. Aquele carimbo errado, equívoco, ficou valendo para o resto das nossas relaçôes até hoje, e a resposta para uma pergunta tão direta e simples poderia ser tão direta e simples quanto. Quando foi que eu atinei que eu tinha de fazer essas coisas que ando fazendo nos últimos 50 anos da minha vida, que é quase que repetir o mesmo mantra, dizendo para esse outro: “ô, cara, essa figura que você está vendo no espelho não sou eu não, é você, esse espelhinho que você está me vendendo não sou eu, isso é um equívoco?"? E saí do sentimento para a prática na pista dos meus parentes mais velhos do que eu, que estavam sendo despachados da zona rural para as periferias miseráveis do Brasil, o que acontece em qualquer canto, no norte, no sul, em qualquer lugar

Este relato da motivação e do sentido do ativismo estético-político, por uma liderança e intelectual tão central do Movimento Indígena brasileiro, como é o caso de Ailton Krenak, aponta para essa perspectiva que argumentamos ao longo do texto, a saber, de que a fala-práxis desde a condição de minoria, seja em sua singularidade, seja nas histórias e nas experiências de marginalização que ela carrega na alma e no corpo, na cultura e na identidade que lhe constituem de modo mais íntimo, é a base de uma perspectiva de crítica social, de reconhecimento cultural, de luta política e de prática pedagógica para uma pluralidade democrática, por uma pluralidade democrática. É ela que permite a desconstrução dos mitos fundacionais que sustentam a modernização conservadora brasileira, principalmente essa compreensão apolítica-despolitizada da colonização e sua afirmação de uma fusão racial que forma a grande família Brasil como um híbrido que contém em si todas as três raças completamente amalgamadas, misturadas ao ponto da indistinção e que, por isso mesmo, elimina diferenciações, contradições e conflitos internos, formando uma unidade indivisa, uniforme e ordenada que apaga de uma vez por todas o passado de violência, que assume uma perspectiva

${ }^{31}$ Ibid., p. 239. 
de inação e de antipolítica e que, ao fim e ao cabo, elimina a possibilidade de uma práxis reparatória calcada na escuta, no reconhecimento e na inclusão das diferenças. É exatamente pela apoliticidade-despolitização dessa grande família Brasil, de caráter híbrido, que se pode continuar derrubando e queimando a mata, expulsando e/ou matando indígenas para expropriá-los de suas terras, matando negros/as nas favelas, negar a homofobia e a transfobia assassinas e aviltar permanentemente nossas mulheres. Por um lado, na grande família Brasil, que teima em se esquecer do seu passado, não temos nenhuma culpa por isso; por outro, nada disso é legitimado por nossa cultura e por nossas instituições. Como disse o presidente Jair Messias Bolsonaro, é provável que os incêndios na Amazônia tenham sido cometidos não pelos fazendeiros, mas pelos/as indígenas e pelas ONGs! Como sempre, os culpados por nossas patologias sociais são as vítimas; os opressores aparecem como vítimas, logo eles que exercem um trabalho inestimável para o crescimento do Brasil, isto é, garantindo, por meio da centralidade de uma economia primária não-tecnológica e de uma cultura de violência e de racismo, o subdesenvolvimento social permanente, o fundamentalismo cultural e o autoritarismo político.

Contra tudo isso, aparece exatamente terceiro ponto que nos parece importante, assumido pelas minorias político-culturais de um modo geral e pela vozpráxis estético-literária indígena em particular, ambas marcadas por uma perspectiva ativista, militante e engajada em torno à sua condição como minorias. Esse ponto é a afirmação e a valorização de sua singularidade e sua utilização dessa singularidade como base para sua reconstrução e para sua postura de crítica do presente. Sua singularidade é o arcabouço paradigmático e o aguilhão normativo garantidores da crítica do presente; no caso dos povos indígenas, a revalorização de sua pertença serve como fundamento para sua postura de ativismo, de militância e de engajamento na esfera público-política. Ao contrário de Peri, nossos/as verdadeiros/as indígenas não têm vergonha de sua condição e nem se sentem inferiores em relação ao branco e à sua cultura. Muito pelo contrário, reconhecem a maravilha de ser diferentes, a riqueza simbólica de suas tradições e pertenças e, finalmente, politizados/as que são, são conscientes de que sua condição, suas histórias e suas experiências, quando vinculadas e publicizadas na esfera pública, põem fogo sim, mas na ignorância, no esquecimento e na despolitização. Essa reafirmação das tradições, essa visão otimista e politizada de sua singularidade e 
essa utilização de suas histórias e experiências como crítica do presente podem ser vistas em três passagens importantes. A primeira, de Kaká Werá, reforçando a pertença como ponto de partida e base de sua autocompreensão e de seu ativismo, sua vinculação com a tradição que dá base à sua identidade pessoal, sempre ligada de modo umbilical ao seu povo:

Eu sou Kaká Werá Jecupé, um Txucarramãe que percorre o caminho do Sol, de acordo com a pintura do urucum escrita nesse corpo que guarda a história milenar de nosso povo, desde os Tubaguaçus primeiros, desde os Coroados primeiros, os primeiros Tupinambás - os adornados da plumagem do arco-íris em cintilantes cocares, os que desde sempre desenham e talham as douradas flechas dos raios de Tupã - pelos tempos, luas e luas ${ }^{32}$

A segunda, de Eliane Potiguara, que imbrica reafirmação da tradição, publicização das experiências de dor, ativismo político e crítica do presente, sempre em nome do povo de que provém, de que faz parte e em nome de quem existe, resiste e luta:

Nosso ancestral dizia: Temos vida longa! / Mas caio da vida e da morte / E range o armamento contra nós. / Mas enquanto eu tiver o coração aceso / Não morre a indígena em mim / E nem tampouco o compromisso que assumi / Perante os mortos / De caminhar com minha gente passo a passo / E firme em direção ao sol. / Sou uma agulha que ferve no meio do palheiro / Carrego o peso da família espoliada / Desacreditada, humilhada / Sem forma, sem brilho, sem fama 33

E a terceira, de Davi Kopenawa, que enfatiza a centralidade e a importância de suas tradiçốes em termos de autocompreensão e de autorrealização, e também

${ }^{32}$ JECUPÉ, Kaká Werá. Oré awé roiru'a ma: Todas as vezes que dissemos adeus: Whenever we said goodbye. Fotos Adriano Gambarini, 2 a ed. rev. e com novas fotos. São Paulo: TRIOM, 2002, p. I5.

${ }_{33}$ POTIGUARA, Eliane. Metade cara, metade máscara. São Paulo: Global, 2004, pp. IO2IO3. 
como base para o diálogo-práxis com a sociedade brasileira envolvente, a partir do reconhecimento de que sua singularidade e do protagonismo que ela possibilita em termos de compreensão e de resolução dos problemas que afetam não apenas os povos indígenas, mas também todos os filhos e todas as filhas da civilização.

Ao contrário, quando bebemos o pó de yãkoana como Omama nos ensinou a fazer, nossos pensamentos nunca ficam ocos. Podem crescer, caminhar e se multiplicar ao longe, em todas as direçôes. Para nós, é esse o verdadeiro modo de conseguir sabedoria.

Apesar de tudo isso, os brancos já nos ameaçaram muitas vezes para nos obrigar a abandonar os xapiri. Nessas ocasióes, só sabiam dizer: "Seus espíritos estão mentindo! São fracos e estão enganando vocês! São de Satanás!”. No começo, quando eu ainda era muito jovem, tinha medo da fala desses forasteiros e, por causa dela, cheguei a duvidar dos xapiri. Por algum tempo, me deixei enganar por essas más palavras e até tentei, com muito esforço, responder às palavras de Teosi. Mas isso acabou mesmo! Faz muito tempo que eu não deixo mais as mentiras dos brancos me confundirem e que não me pergunto mais: "Por que não tento virar um deles?". Tornei-me homem, meus filhos cresceram e tiveram seus próprios filhos. Agora, nunca mais quero ouvir más palavras sobre os xapiri! Omama os criou depois de ter desenhado nossa floresta e, desde então, eles continuaram cuidando de nós. Eles são muito valentes e muito bonitos. Seus cantos fazem nossos pensamentos aumentar em todas as direçôes e ficar firmes. E por isso vamos continuar fazendo dançar suas imagens e defendendo suas casas, enquanto estivermos vivos. Somos habitantes da floresta. É esse o nosso modo de ser e são estas as palavras que quero fazer os brancos entenderem ${ }^{34}$

${ }^{34}$ KOPENAWA, Davi; ALBERT, Bruce. A queda do céu: palavras de um xamã yanomami. São Paulo: Companhia das Letras, 20I5, pp. 5IO-5II. 


\section{Considerações finais}

Uma das bases para a construção de uma versão apolítica e despolitizada de modernização conservadora brasileira foi formulada e justificada em termos de literatura indianista, que possui uma continuidade e um alinhamento surpreendentes com os relatos da colonização, do contato. Era o colonizador, o modelo de homem europeu, branco e cristão, detentor da cultura e da civilização, representante delas, que falava sobre o índio selvagem, rude, inferior e animalizado. José de Alencar ou não pôde ou não quis se libertar dessa posição. Nós já não podemos louvá-lo pura e simplesmente, mas lê-lo nesse caráter contraditório que é próprio de seu tempo - ele e a literatura indianista contribuíram para a formação simbólico-normativa de nossa identidade como nação, mas de um modo enviesado, caricato, colonial, apolítico-despolitizado. Caráter contraditório não só de seu tempo, mas de nosso tempo, uma vez que ele é nossa herança e nós ainda vivemos muitas das ideias emanadas por seu tempo como se fossem o horizonte normativo e paradigmático para tratarmos nossas minorias político-culturais e, de um modo mais geral, a nós mesmos. Jair Messias Bolsonaro não é o causador do caos que estamos vivendo nos últimos tempos; ele é uma consequência da própria modernização conservadora que se sustenta em termos de esquecimento, negação, despolitização. Com efeito, nossa modernização conservadora justificou a colonização como uma tarefa humanitária, civilizacional, como uma experiência de protagonismo rumo ao desenvolvimento e à integração, em que o desbravador, o bandeirante, o fazendeiro vêm de outro país para o nosso, vai do sudeste para o sul e deste para o norte, para o nordeste e para o centro-oeste, trazendo civilização, desenvolvimento, qualidade de vida. Esse é o mito da colonização que subjaz - atual, vivo, pulsante, plenamente ativo - no dia a dia de nossa cultura e que justifica, ainda hoje, a derrubada e a queima da mata, a exploração do solo e, em tudo isso, a expulsão dos/as indígenas de suas terras. Ainda hoje, portanto, o/a indígena é a antítese da civilização e a massa informe que precisa ser moldada pelo progresso, situação que os fazendeiros, de modo exclusivo, têm condições de fazêlo e querem fazê-lo. Por isso, é tempo de uma releitura de nossa história nacional e de uma reconstrução de nossa literatura fundadora, em particular o indianismo. Assim como é tempo de consolidação das minorias na política, na educação, na cultura, elas que nos trazem a renovação, o aprendizado e a mudança. Viveram 
na alma e no corpo, na identidade e na cultura, a violência simbólico-material colonial e sobreviveram ao etnocídio; com sua dor e com seu sangue, com suas experiências e histórias de marginalização, mas também de redenção, de resistência, de comunhão e de participação, nos ajudarão a forjar o Brasil do futuro, não mais uma família unitária, indivisa, desmemoriada e apolítica que nega seu passado e esconde seus problemas, mas uma pluralidade pujante, interativa e crítica do que foi, do que é e do que virá a ser.

\section{Referências}

ALENCAR, José de. Oguarani. 2 ed. Barueri, SP: Ciranda Cultural, 2017 [I857]. . Iracema. Porto Alegre: L\&PM, 2017 [I865]. . Ubirajara. Paris: Imp. Paul Dupont (Cl.), 1926 [1874].

BOSI, Alfredo. História concisa da literatura brasileira. sI ed. São Paulo: Cultrix, 2017.

CUNHA, Manuela Carneiro da. Índios no Brasil: história, direitos e cidadania. I

GAMBINI, Roberto. Espelho indio: a formação da alma brasileira. Coordenação Mary Lou Paris, Caio Kulgemas. São Paulo: Axis Mundi: Terceiro Nome, 2000.

GANDAVO, Pero de Magalhães. Tratado da terra do Brasil; História da província de Santa Cruz. Belo Horizonte: Ed. Itatiaia. São Paulo: Ed. da Universidade de São Paulo, 1980 [1826]).

JECUPÉ, Kaká Werá. Oré awé roiru'a ma: Todas as vezes que dissemos adeus: Whenever we said goodbye. Fotos Adriano Gambarini, 2 $\underline{a}$ ed. rev. e com novas fotos. São Paulo: TRIOM, 2002.

KOPENAWA, Davi; ALBERT, Bruce. A queda do céu: palavras de um xamã yanomami. São Paulo: Companhia das Letras, 2015.

KRENAK, Ailton. Encontros. Organização de Sérgio Cohn. Rio de Janeiro: Azougue Editorial, 2015.

MUNDURUKU, Daniel. Histórias de indio. Ilustrações Laurabeatriz. 2aㅡ ed. São Paulo: Companhia das Letrinhas, 2016. . Coisas de indio. Versão infantil. 2.ed. São Paulo: Callis Ed., 20 oro. 
Especiais, 2019.

. Ensaios poéticos de Daniel Munduruku. 2. Ed. Lorena: DM Projetos . Sobre vivências, piolhos e afetos. Mundurukando 2. Lorena, SP: UK'A editorial, 2017.

OLIVIERI-GODET, Rita. A alteridade amerindia na fiç̧ão contemporânea das Américas: Brasil, Argentina, Quebec. Belo Horizonte, MG: Fino Traço, 2013. POTIGUARA, Eliane. Metade cara, metade máscara. Lorena: UK’A Editorial, 2018.

POTIGUARA, Eliane. Metade cara, metade máscara. São Paulo: Global, 2004. ROSA, Francys Mary Soares Correia da. "Representações do indígena na literatura brasileira”. In: DORRICO, Julie; DANNER, Leno Francisco; CORREIA, Heloisa Helena Siqueira; DANNER, Fernando. Literatura indigena brasileira contemporânea: criação, crítica e recepção. Porto Alegre, RS: Editora $\mathrm{Fi}, 2018$.

SÁ, Lúcia. Literaturas da floresta: textos amazônicos e cultura latino-americana. Rio de Janeiro: EdUERJ, 2 oI2.

STADEN, Hans. Duas viagens ao Brasil: Primeiros registros sobre o Brasil. Tradução Angel Bojadsen; Introdução Eduardo Bueno. Porto Alegre, RS: L\&PM, 2017.

TABAJARA, Auritha. Coração na aldeia, pés no mundo. Xilografias de Regina Drozina. I

TREECE, Dave. Exilados, aliados, rebeldes: o movimento indianista, a política indigenista e o Estado-nação imperial. São Paulo: Nankin: Edusp, 2008.

WERÁ, Kaká. Kaká Werá. Coordenação de Sergio Cohn e de Idjahure Kadiwel. Rio de Janeiro: Azougue Editorial, 2017 (Coleção Tembetá).

Resumo: Tematizamos a imagem, o lugar e o protagonismo do/a indígena na formação da cultura e da identidade nacionais a partir de uma contraposição entre a literatura indianista, em que o colonizador fala sobre o/a indígena, e a literatura indígena contempo-
Abstract: We thematize the image, the place and the protagonism of the Indian in the formation of national culture and identity, from a contraposition between the Indianist literature, in which the colonizer speaks about the Indian, and the contempo- 
rânea, em que o/a próprio/a indígena fala de si mesmo/a e por si mesmo/a, a partir de suas experiências e histórias como minoria político-cultural produzida pela colonização e sustentada em termos de modernização conservadora. O que impressiona nessa discussão é o fato de que o/a indígena como antítese da civilização e como massa amorfa a ser moldada para a consecução do novo mundo justifica tanto a colonização quanto o processo contemporâneo, servindo de objeto para a legitimação de processos institucionais, de sujeitos sociopolíticos e de projetos de desenvolvimento que implicam na aniquilação do/a indígena como indígena. Em tudo isso, o mito da fusão racial é a grande base normativa de nossa modernização conservadora, pois, ao gerar o híbrido brasileiro como mistura e amálgama indiferenciados de todas as raças em um novo ser, que é e tem tudo de todos, apaga as fronteiras entre dominadores $\mathrm{e}$ dominados e, com isso, resolve de modo apolítico a história de violência da colonização, formando a grande família Brasil que não precisará mais da política, mas apenas da ordem autoritária e da obediência cega, para resolver seus problemas de família.

Palavras-Chave: Indianismo; Indígena; Identidade Nacional; Ativismo; Politização. rary Indian literature, in which the own Indian speaks from himself/herself, from his/her experiences and histories as political-cultural minority made by colonization and sustained in terms of conservative modernization. What is very impressive in this discussion is the fact that the Indian as antithesis of civilization and as amorphous mass to be molded for the consecution of the new world that justifies both colonization and contemporary process, serving as object to the legitimation of institutional processes, social-political subjects and projects of development that implicate in the annihilation of the Indian as Indian. In all this, the myth of racial fusion is the great normative basis of our conservative modernization, because, by generating the Brazilian hybrid as a undifferentiated mix and amalgam of all races into a new being, who is and has all of everyone, erases the frontiers between dominant and dominated and, then, resolves in an apolitical way the history of violence of the colonization, constituting the great family Brazil that will not need politics anymore, but authoritarian order and full obedience, to resolve its familiar problems.

KeYwords: Indianism; Indian; National Identity; Militancy; Politicization. 